\title{
Comparing Legal Approaches: Mental Disorders as Grounds for Excluding Criminal Responsibility
}

\author{
CARL-FRIEDRICH STUCKENBERG ${ }^{\star}$
}

\section{Historical Introduction}

It seems that mental disturbances have served as valid excuses from liability and punishment from time immemorial. In the Iliad, King Agamemnon disowns his offending actions by claiming that

\begin{abstract}
It was not I that did it: Zeus and Fate, and Erinys that walks in darkness struck me mad when we were assembled on the day that I took from Achilles the prize that had been awarded to him. What could I do? All things are in the hand of heaven, and Folly [Ate], eldest of Zeus' daughters, shuts men's eyes to their destruction. ${ }^{1}$
\end{abstract}

Whether explained as possession by gods or demons, or in the naturalistic way of the Galenic school ${ }^{2}$ as a disease of the brain, ancient law usually put persons with obvious mental disorders in the care of their families and exempted them from criminal responsibility, though not necessarily from civil liability. This is also reflected in Plato's Laws (IX, 864) and Aristotle's Nicomachean Ethics (1111a). Ancient Roman law regarded the insane (furiosi), like children, as incompetent to act because compotes mentis non sunt, hence, they were not responsible for a crime, even for patricide or homicide, unless committed

Professor of German and international criminal law and criminal procedure, comparative criminal law and criminal law history, Rheinische Friedrich-Wilhelms-Universität Bonn, Germany.

1 Homer, Iliad, XIX, p. 86 ff. (Lattimore translation, University of Chicago Press 1951).

2 Cf. Daniel Robinson, Wild Beasts \& Idle Humours (Harvard University Press 1996) p. 61 with further ref.

This is an Open-access article distributed under the terms of the Creative Commons Attribution 3.0 Unported License (http://creativecommons.org/ licenses/by/3.0/), permitting all use, distribution, and reproduction in any medium, provided the original work is properly cited. 
in a lucidum intervallum. It was also said that their ill fate excused them or that they were already punished by their madness. ${ }^{3}$ Medieval Canon law followed Roman doctrine $e^{4}$, which was reinforced by the Augustinian teaching that sin requires voluntariness which is lacking in those qui usu rationis carent. ${ }^{5}$

The Continental European ius commune kept the Roman doctrines and phrases, extended the reason of doli incapacitas from wild beasts and children to the insane, and added the humane consideration that those who already are suffering from illness should not be further burdened by punishment: ${ }^{6}$

furiosus et infans non sunt capaces delicti, sic nec animalia bruta, et ideo factum ab eis fit impune, quia est factum sine dolo et culpa ${ }^{7}$

(6) Excusantur item enim hac ratione furiosi \& phrenetici, qui ob animi impotentiam, mentis suae non sunt compotes, eoque ex deliberato animo nihil facientes, nec quid faciant, scientes. Nam tales nullo modo puniuntur ... cum eos fati infelicitas excuset, \& mentis inopia. ... (8) Alia praeterea est ratio naturalis magis, quod furiosus satis suo furore torquetur ac punitur ... Nec afflicto addenda est afflictio... ${ }^{8}$

However, until the 19th century, there was no refined doctrinal concept of imputabilitas and usually all problematic cases were subsumed under doli incapacitas. ${ }^{9}$ Early enlightenment codifications were also brief:

Wer frey zu handeln unvermögend ist, bey dem findet kein Verbrechen, also auch keine Strafe statt. ${ }^{10}$

D. 1, 18, 13, 1; 18, 1, 14; 29, 5, 3, 11: 'Furiosos excipi nequaquam dubium est.'; 48, 8, 12: 'Infans vel furiosus si hominem occiderint, lege Cornelia non tenentur, cum alterum innocentia consilii tuetur, alterum fati infelicitas excusat.'; 48, 9, 9, 2: 'nam sufficere furore ipso eum puniri'. See Mommsen, Römisches Strafrecht (Duncker \& Humblot 1899) p. 77 n. 1 with further ref.

4 Decretum Gratiani, C. 15 q. 1 c. 2: 'Furor autem, cum non sit peccatum, est tamen pena peccati ...'

5 The 1912 Codex Iuris Canonici says in can. $2201 \$ 1$ : 'Delicti sunt incapaces qui actu carent usu rationis.' with a presumption against lucida intevalla; $₫ 4$ : 'debilitas mentis delicti imputabilitatem minuit, sed non tollit omnino., see now the 1983 Codex, can. 1322: 'Qui habitualiter rationis usu carent, etsi legem vel praeceptum violaverint dum sani videbantur, delicti incapaces habentur.' and can. 1323 no. 6 .

$6 \quad$ See also Constitutio Criminalis Carolina (1532) art. 164, 179.

7 Baldus s. D.v. ad 1. Aquil. l. injuriarum.

$8 \quad$ Damhouder, Praxis rerum criminalium (Antverpiae 1601) cap. 86 n. 6 ff.

$9 \quad C f$. Böhmer, Elementa iurisprudentiae criminalis, 6th ed. (Halae 1766) sect. I, ch. II, $\$ \$$ XL f.: ` $\$$ L. Quum vero non omnes actiones legum criminalium obiectum constituant, sed spontaneae (...), spontaneitas vero sine dolo vel culpa concipi nequeat; certissimi iuris est: qui doli vel culpae non est capax, crimen committere nequit [...] \$ XLI. Sequitur inde, non delinquere 1) furiosos ac mente captos ... 2) dormientes ... 3) facilius summe ebrios ... 4) infantes ... iratos ... 5) surdos et mutos, 6) stupidos, vel 7) prodigos.'

$10 \quad$ Allgemeines Landrecht für die Preußischen Staaten (PrALR 1794) 20 II $\$ 16$. 
Il n’y a ni crime ni délit, lorsque le prévenu était en état de démence au temps de l'action .. $^{11}$

Early English law essentially took the same position: Those who were not compos mentis when they acted could not be punished, even for treason. ${ }^{12}$ Coke deduced this from the end of punishment:

... for the principall end of punishment is, that others by his example may feare to offend, ut poena ad paucos, metus ad omnes perveniat; but such punishment can be no example to mad-men, or infants ... ${ }^{13}$ [and:] furiosus solo furore punitur ${ }^{14}$

However, this applies only to perfect madness or 'total alienation of the mind' with the traditional exception of lucid intervals, whereas partial insanity is not an excuse because, as Hale remarked, most felons 'are under a degree of partial insanity when they commit these offenses. ${ }^{15}$ Blackstone reasoned that all crimes are constituted by a 'vitious will' and an overt unlawful act 'consequent upon such vitious will'. ${ }^{16}$ Thus there can be no crime in cases in which 'the will does not join with the act', for instance because of a 'general defect of understanding, like infancy, idiocy, lunacy, and intoxiction.' ${ }^{17}$

$11 \quad$ French Code pénal (1810), art. 64.

12 This also applies when a sane offender becomes mad after he committed an act of treason. The common law held that he cannot be executed; a 'cruell and inhuman' statute of Henry VIII which allowed such execution, was soon repealed because 'the execution of the offender is for example ... but so it is not when a mad man is executed, but should be a miserable spectacle, both against law, and of extreame inhumanity and cruelty, and can be no example to others.', Coke, The Third Part of the Institutes of the Laws of England (1641) (London: W. Clark and Sons 1817) ch. I, p. 6; Blackstone, Commentaries on the Laws of England (Oxford: Clarendon Press 1769) vol. 4 ch. 2 p. 25 .

13 Coke, ibid., p. 4.

14 Coke, ibid., p. 6.

15 Hale, Historia Placitorum Coronae, The History of the Pleas of the Crown (1736) (London: Printed by E. Ryder 1800) vol. I ch. IV fol. 30.

$16 \quad$ Blackstone 1769 vol. 4 ch. 2 p. 21.

17 Blackstone, ibid:: 'For where there is no discernement, there is no choice; and where there is no choice, there can be no act of the will, which is nothing else but a determination of one's choice, to do or to abstain from a particular action; he therefore, that has no understanding, can have no will to guide his conduct.'; ibid., ch. 2 p. 24: 'For the rule of law as to the latter, ..., is, that "furiosus furore solum punitur". In criminal cases therefore idiots and lunatics are not chargeable for their own acts if committed when under these incapacities ...'; ibid., ch. 2 p. 25: '... a total idiocy, or absolute insanity, excuses from the guilt, and of course from the punishment, of any criminal action committed under such deprivation of the senses; but if a lunatic hath lucid intervals of understanding, he shall answer for what he does in those intervals, as if he had no deficiency.' 
By the end of the 16th century, English courts had begun to apply the Biblical test of moral capacity, ${ }^{18}$ namely ' knowledge of good and evil', to the insane. ${ }^{19}$

\section{Comparative Survey}

It has been alleged that the 'effect of insanity on criminal responsibility is an issue which is common to all human societies, ${ }^{20}$ however, the practical effects vary considerably and this discord has increased even more in the past 30 years. To date, a comparative survey ${ }^{21}$ shows that there are three basic approaches to deal with mental disorders as grounds for excluding criminal responsibility (I will not address the procedural dimension, i.e. unfitness to stand trial), namely:

(1) The overwhelming majority of legal orders accept mental disorder as separate ground - mostly labelled 'excuse' or 'defence' - for excluding criminal responsibility. Although the criteria look very similar, the resulting practical differences range from very restrictive application, notably in the English-speaking world, to fairly frequent use in some civil law countries.

(2) A small group of legal orders - a couple of American states - admits mental disorders only insofar as they constitute mistake or involuntariness, i.e. negate the requirement of intent or, rather in theory than in practice, of a voluntary act.

(3) Another small group - mainly Sweden which, however, is gradually returning to the mainstream - adopted a unified system of social control in which mental disorders are only relevant to determine the suitable kind of treatment of the offender.

\subsection{Mental Disorder as Complete Excuse}

The majority of legal orders consider a certain soundness of mind at the time of the commission of the offence to be a fundamental prerequisite of criminal responsibility. This prerequisite forms part of a broader category, commonly called imputabilitas, guilt/responsibility, responsabilité pénale, imputabilidad, or Zurechnungsfähigkeit/Schuld, which

18 See Platt \& Diamond, 54 Cal.L.Rev. (1966) pp. 1227-1260, at 1227-1228.

19 Dalton, The Countrey Justice (London: Company of Stationers 1655) p. 306 [244]; see Platt \& Diamond 1966 pp. $1233 \mathrm{ff}$.

$20 \quad$ Yeo, Sing. J. Legal Stud. (2008) pp. 241-263, at 242.

21 Cf. also Sparr, 37 J. Am. Acad. Psychiatry \& L. (2009), pp. 168-181, at 172 ff.; Yeo 2008 pp. 241-263; Simon \& Ahn-Redding, The insanity defense, the world over (Lexington Books 2006); Loughnan, Manifest Madness (Oxford University Press 2012) pp. 26 ff. 
is commonly linked to naïve conceptions of freedom of will, i.e. the ability to choose between right and wrong. If that condition is not present due to a mental disorder, no crime exists and no punishment ensues. ${ }^{22}$ This category of 'guilt' has constitutional status in some states (Germany, Italy, Canada; not in the U.S.).

\subsubsection{Criteria}

\subsubsection{One-dimensional/single criterion tests ('Medical Approach')}

There is at least one state - maybe today (see French Code pénal of 1810) only one -, Norway, ${ }^{23}$ which uses a one-dimensional medical approach. This means that the mere presence of e.g. a psychosis, in the sense of a significantly disturbed relationship to reality at the time of committing the criminal act, is sufficient to exempt the accused from punishment. A possible explanation of this approach is that it rests on the tacit, irrebuttable presumption that the accused's conduct was 'the product' of his mental disorder or that the mere possibility of the illness having contributed to the conduct is deemed sufficient, ${ }^{24}$ in light of the assumed difficulty or impossibility to prove that causal link..$^{25}$

\subsubsection{Dualist tests ('Mixed Approach')}

Most legal orders employ what by some writers has been called the 'biological-psychological method, ${ }^{26}$ i.e. a test comprising two criteria. The first is a descriptive one relating to some mental defects while the second is a psychological or functional one requiring

$22 \quad$ E.g. PrALR (1794) 20 II $\$ 16$, supra note 10.

23 See sec. 20(1)(b) of the new Norwegian Penal Law of 20 May 2005 which entered into force on 1 October 2015, and sec. 44 of the previous General Civil Penal Code of 1902 ('A person who was psychotic or unconscious at the time of committing the act shall not be liable to a penalty. The same applies to a person who at the time of committing the act was mentally retarded to a high degree.'). 'Psychosis' is understood as a legal term which is largely, but not entirely coextensive with the medical diagnosis. See the detailed discussion in the judgment of the Oslo District Court judgment of 24 August 2012 in the '22 July' (Breivik) case, pp. 49 ff., available at https://lovdata.no/ static/file/834/toslo-2011-188627-24e.pdf. This case has spurred law reform efforts, yet without results so far; compare the resume of the proposals of the royal committee by Gröning \& Rieber-Mohn, 3 Bergen J. Crim. L. \& Crim. Just. (2015) pp. 109-131; see also Aarli, Reform of the Insanity Defense: Norwegian Reflections post 22 July 2011, in: The Future of Criminal Law?, eds. Dempsey, Duff, Hoskins \& Jain (Robina Institute of Criminal Law and Criminal Justice 2014) pp. 113-123.

24 Cf. Cornils \& Husabø (eds.), Das norwegische Strafgesetz/Lov om straff (straffeloven) (Berlin: Duncker \& Humblot 2014) p. 46.

25 Cf. Gröning \& Rieber-Mohn 2015 pp. 114-115.

26 Robert von Hippel, Deutsches Strafrecht (Berlin: Julius Springer 1930) vol. 2 pp. 289 ff. 
certain inabilities as a result of the mental defect. As a consequence, a third criterion is tacitly implied, namely the causal connection between mental disorder and functional impairment.

\subsection{Biological and Medical Categories: Type of Disorder}

The descriptions of the mental disorders in the first prong of the test often use colloquial expressions like 'insanity' in English or 'démence' in French. Sometimes old terms, common even in 19th century medical parlance which today would appear derogatory and unsuitable, like 'madness', 'lunacy', 'idiocy', 'debility' or 'mental abnormality', are still used. Older laws often treated deaf-mutes like the insane. The cause of the mental disorder mostly is of no concern, whether it is a 'disease of the mind' or psychosis like schizophrenia, bipolar disorder, but also epilepsy, somnambulism, certain psychoneuroses, hyper- and hypoglycemia etc., or a 'defect' or 'natural mental infirmity' the person was born with, like abnormally low intellect, $c f$. Model Penal Code $\$$ 4.01(1): 'mental disease or defect'. Some formulations are so broad as to cover temporary disabilities like intoxication (e.g. Continental European countries) whereas others are eager to exclude self-induced disturbances, notably substance abuse ${ }^{27}$ or ' repeated criminal or otherwise antisocial conduct' ( $\$ 4.01(2) \mathrm{MPC}$ ). If a legal distinction is made between insanity and intoxication, as in the Common Law tradition, the border zone of alcoholism, delirium tremens or singular events of alcoholic psychosis is likely to pose problems. ${ }^{28}$

It is noteworthy that most ${ }^{29}$ of these descriptions are made in legal terms and not in medical or clinical terms. Nowhere, I have found references to international classificatory schemes like the ICD-10 (International Classification of Diseases) of the World Health Organization or the DSM-V (Diagnostic and Statistical Manual of Mental Disorder, 5th edition, 2013) of the American Psychiatric Association. This separation of legal from medical descriptors has the obvious advantage of freeing the law from the vagaries of the development of the medical sciences - avoiding the problems created by outdated terminology which plague $\$ 20$ of the German Criminal Code ('pathological mental disorder, profound consciousness disorder, debility or any other serious mental abnormality'). On the other side, the separation has the obvious disadvantage of potentially missing essential features of the relevant phenomena and of creating permanent problems of translation in the legal evaluation of expert opinions.

$27 \quad$ Part I s. 1 and 27 Criminal Code of Western Australia.

$28 \quad C f$. Model Penal Code, Comment 2 to $\$ 2.08$, vol. 2, pp. $360 \mathrm{ff}$.

29 But see former s. $428 \mathrm{~B}$ of the Crimes Act of the Australia Capital Territory, now replaced by s. 28 of the ACT's Criminal Code 2002 (A2002-51), defined 'mental dysfunction' as 'a disturbance or defect, to a substantially disabling degree, of perceptual interpretation, comprehension, reasoning, learning, judgment, memory, motivation or emotion. 


\subsection{Psychological/Functional Impairments}

The second prong of the test frequently is more controversial than the first one. The second criterion has the task to examine whether the mental disorder eliminated a necessary condition of criminal responsibility or not. Whereas older rules asked whether 'free will' or the 'freedom to act' was destroyed, ${ }^{30}$ most modern formulations ask for specific cognitive and/or volitional defects which affect the normal functioning of the mechanism of the naïve model of action implicit in the concept of criminal conduct. Practically nowhere, ${ }^{31}$ the modern psychiatric definition of mental illness as 'a pervasive inability to engage in reality ${ }^{32}$ has been adopted.

\subsection{Civil Law}

Many civil law jurisdictions, including Russia and the Far East as well as Islamic law, are fairly uniform in employing an alternative test which asks if the defendant was unable either to understand the (legal) wrongfulness of his conduct (cognitive defect) - this is nothing else than a mistake of law due to the medical condition - or to act in accordance with his appreciation of the wrongness of his conduct (volitional/conative defect):

Germany, Criminal Code, $\$ 20$ : Any person who at the time of the commission of the offence is incapable of appreciating the unlawfulness of their actions or of acting in accordance with any such appreciation due to a pathological mental disorder, a profound consciousness disorder, debility or any other serious mental abnormality, shall be deemed to act without guilt.

Spain, Código penal, art. 20: Están exentos de responsabilidad criminal: $1 .{ }^{\circ}$ El que al tiempo de cometer la infracción penal, a causa de cualquier anomalía o alteración psíquica, no pueda comprender la ilicitud del hecho o actuar conforme a esa comprensión. [...] 3. ${ }^{\circ}$ El que, por sufrir alteraciones en la percepción desde el nacimiento o desde la infancia, tenga alterada gravemente la conciencia de la realidad.

Italy, Codice penale, art. 88 (Vizio totale di mente): Non è imputabile chi, nel momento in cui ha commesso il fatto, era, per infermità, in tale stato di mente da escludere la capacità d'intendere o di volere. strafbare Handlung ist nicht vorhanden, wenn der Thäter zur Zeit der Begehung der Handlung sich in einem Zustande von Bewußtlosigkeit oder krankhafter Störung der Geistestätigkeit befand, durch welchen seine freie Willensbestimmung ausgeschlossen war.

$31 \quad$ But see note 27.

32 Finbarr McAuley, Insanity, Psychiatry and Criminal Responsibility (Dublin: Round Hall 1993) p. 35 . 
France, Code pénal of 1995, art. 122-1: N’est pas pénalement responsable la personne qui était atteinte, au moment des faits, d'un trouble psychique ou neuropsychique ayant aboli son discernement ou le contrôle de ses actes.

Turkey, Ceza Kanunu of 2004, art. 32(1): A person lacking ability to perceive the legal meaning and consequences of the offense, or having considerably lost the capacity to control his actions due to insanity may not be subject to any punishment. However, security precautions are imposed for such individuals.

Poland, Kodeks karny, art. $31 \$ 1$ : Whoever, at the time of the commission of a prohibited act, was incapable of recognising its significance or controlling his conduct because of a mental disease, mental deficiency or other mental disturbance, shall not commit an offence.

Russian Federation, Criminal Code, art. 21 (Insanity): 1. A person who, at the time of the commission of a socially dangerous act, was insane, that is, was unable to understand the actual character or social danger of his actions (inaction) or to govern them as a consequence of a chronic or temporary mental derangement, mental deficiency or any other mental condition, shall not be subject to criminal responsibility.

Argentina, Código Penal of 1984, art. 34: No son punibles: $1^{\circ}$. El que no haya podido en el momento del hecho, ya sea por insuficiencia de sus facultades, por alteraciones morbosas de las mismas o por su estado de inconciencia, error o ignorancia de hecho no imputables, comprender la criminalidad del acto o dirigir sus acciones.

Brazil, Código Penal of 1940/1984, art. 26: É isento de pena o agente que, por doença mental ou desenvolvimento mental incompleto ou retardado, era, ao tempo da ação ou da omissão, inteiramente incapaz de entender o caráter ilícito do fato ou de determinar-se de acordo com esse entendimento.

People's Republic of China, Criminal Code of 1997, art. 18: A mentally ill person who causes dangerous consequences at a time when he is unable to recognize or unable to control his own conduct is not to bear criminal responsibility after being established through accreditation of legal procedures; but his family or guardian shall be ordered to subject him to strict surveillance and arrange for his medical treatment. When necessary, he will be given compulsory medical treatment by the government. [...]

South Korea, Criminal Law, art. 10: (1) The act of a person who, because of mental disorder, is unable to make discriminations or to control one's will, shall not be punished.

Codex Iuris Canonici 1983, can. 1322: Qui habitualiter rationis usu carent, etsi legem vel praeceptum violaverint dum sani videbantur, delicti incapaces habentur.

Iran, New Islamic Penal Code, 2013, Book I, art. 140: Criminal responsibility in the cases of hudud, qisas, and ta'zirat shall be established only when the individual is sane, pubescent, and free at the time of commission of the offense, with the exception of coer- 
cion to murder which has been dealt with in the Third Book Qisas.

art. 149: 'When the offender at the time of commission of an offense had been

suffering from a mental disorder in a way that s/he had no intention or sense of

discernment, s/he shall be regarded as insane and has no criminal responsibility.

\subsection{Common Law}

The situation is more complicated in legal orders belonging to the English law tradition. The English law on insanity is still governed by the so-called M'Naghten rules of 1843 . The Law Commission has published a discussion paper in $2013,{ }^{33}$ but no final report and no legislative action has ensued so far. The Scottish woodturner Daniel M'Naghten suffered from the paranoid delusion that he was being persecuted by the Tories. Consequently, he attempted to kill the Prime Minister Peel, but by mistake shot his private secretary Edward Drummond who died five days later. M'Naghten was found 'not guilty' of murder, on the ground of insanity, and spent the rest of his life, 21 years, in lunatic asylums. The acquittal caused a public outcry because of its leniency and Queen Victoria feared that cranks and radicals could be encouraged to make attempts on her life. The House of Lords asked the judges of Queen's Bench to advise them on the relevant legal principles and the resulting answer, in essence, was this:

the jurors ought to be told in all cases that every man is to be presumed to be sane, and to possess a sufficient degree of reason to be responsible for his crimes, until the contrary be proved to their satisfaction; and that to establish a defence on the ground of insanity, it must be clearly proved that, at the time of committing of the act, the party accused was labouring under such a defect of reason, from disease of the mind, as not to know the nature and quality of the act he was doing: or, if he did know it, that he did not know he was doing what was wrong. The mode of putting the latter part of the question to the jury on these occasions has generally been, whether the accused at the time of doing the act knew the difference between right and wrong ... ${ }^{34}$

Concerning delusions about existing facts, the judges added:

[if] he labours under such partial delusion only, and is not in other respects insane, we think he must be considered in the same situation as to responsibility as if the facts with respect to which the delusion exists were real. For example, if under the influence of his

33 Law Commission, Criminal Liability: Insanity and Automatism, A Discussion Paper (23 July 2013), see in particular $\$ 4.160$ : 'Proposal 3: The party seeking to raise the new defence must adduce expert evidence that at the time of the alleged offence the defendant wholly lacked the capacity: (i) rationally to form a judgment about the relevant conduct or circumstances; (ii) to understand the wrongfulness of what he or she is charged with having done; or (iii) to control his or her physical acts in relation to the relevant conduct or circumstances as a result of a qualifying recognised medical condition.'

$34 \quad$ R. v. M'Naghten, 10 Clark \& Finnelly 200, 210; 8 E.R. p. 718, 722 f. (1843). 
delusion he supposes another man to be in the act of attempting to take away his life, and he kills that man, as he supposes, in self-defence, he would be exempt from punishment. ${ }^{35}$

Apart from their questionable authority as advisory opinion, the M'Naghten rules were controversial from the outset ${ }^{36}$ and remain so until today. ${ }^{37}$ This is both because they reduce the issue of insanity to a case of cognitive defect belonging to the categories of innocent mistake of fact or law and disregard the possibility that mental disorders may also affect, as Stephen put it, 'the emotions and the will.' ${ }^{38}$

In some common law jurisdictions, the M'Naghten rules were supplemented by a volitional prong like an 'irresistible impulse' test already used in earlier English cases. ${ }^{39}$ The majority of Commonwealth jurisdictions today recognise cognitive defects alongside volitional ones, ${ }^{40}$ although the practical experiences vary widely. Variations also occur in the cognitive prong, whether accused must only 'know' or 'appreciate' i.e. understand what he is doing, whether the distinction of right and wrong refers to legal or moral wrongness, and e.g. whether persons acting on divine commandments or 'deific decrees' shall count as insane.

In the United States of America, the development of the law on insanity took a somewhat different and, in recent times, more disturbing course. The M'Naghten rules were readily accepted and in some places combined with an 'irresistible impulse' test. In

R. v. M'Naghten, 10 Clark \& Finnelly 200, 210; 8 E.R. p. 718, 722 f. (1843).

Cf. Stephen, A History of the Criminal Law of England (London: Macmillan and Co. 1883) vol. 2 pp. $155 \mathrm{ff}$.

Cf. Ashworth \& Horder, Principles of Criminal Law, 7th ed. (Oxford University Press 2013) pp. $143 \mathrm{ff}$.

Stephen 1883 p. 155; see also the Law Commission's proposal, supra note 32.

R. v. Oxford, 9 Car. \& P. p. 525, 546; 173 E.R. p. 941, 950 (1840).

Yeo 2008 p. 254 with further references. E.g. Australian Model Penal Code (2009), § 2.3.3 (Mental impairment): '(1) A person is not criminally responsible for an offence if, at the time of carrying out the conduct constituting the offence, the person was suffering from a mental impairment that had the effect that: (a) the person did not know the nature and quality of the conduct, or (b) the person did not know that the conduct was wrong (that is, the person could not reason with a moderate degree of sense and composure about whether the conduct, as perceived by reasonable people, was wrong), or (c) the person was unable to control the conduct.'; South Africa, Criminal Procedure Act of 1977, s. 78 (Mental illness or mental defect and criminal responsibility): '(1) A person who commits an act or makes an omission which constitutes an offence and who at the time of such commission or omission suffers from a mental illness or mental defect which makes him or her incapable - (a) of appreciating the wrongfulness of his or her act or omission; or (b) of acting in accordance with an appreciation of the wrongfulness of his or her act or omission, shall not be criminally responsible for such act or omission.'; Israel Penal Law (Law No. 626/1996), s. 34H: 'A person shall bear no criminal responsibility for an act done by him if, at the time of the act, because of an illness affecting his psyche or a defect in his intellectual ability, he is not actually able- (1) to understand what he is doing or the wrongness of his act; or (2) to refrain from doing the act.'. 
1954, at a time which experienced heightened interest in psychology and psychiatry, a federal insanity test was formulated by the D.C. Circuit court in Durham v. United States which held that:

an accused is not criminally responsible if his unlawful act was the product of mental disease or mental defect. ${ }^{41}$

This test was hailed by the medical profession but proved difficult to apply. The Model Penal Code, published in 1962, used a two-pronged test similar to European models:

$\$$ 4.01(1) A person is not responsible for criminal conduct if at the time of such conduct as a result of mental disease or defect he lacks substantial capacity either to appreciate the criminality [wrongfulness] of his conduct or to conform his conduct to the requirements of the law.

A majority of state criminal laws, as well as federal circuit courts subsequently followed the Model Code more or less closely. Yet, quite a number of critical voices, among them President Nixon, advocated the abolition of the insanity defence for a variety of reasons, notably its 'unconscionable abuse' (Nixon) which let too many wrongdoers escape punishment. ${ }^{42}$ The opponents gained momentum after 1981 when John Hinckley tried to murder President Reagan in order to gain the attention of the actress Jodie Foster and was acquitted on the ground of volitional incapacity under the MPC test adopted by the D.C. circuit court. ${ }^{43}$ The federal Insanity Defense Reform Act (IDRA) ${ }^{44}$ of 1984 essentially returned to M'Naghten:

18 U.S.C. $\$ 17($ a): It is an affirmative defense to a prosecution under any Federal statute that, at the time of the commission of the acts constituting the offense, the defendant, as a result of a severe mental disease or defect, was unable to appreciate the nature and quality or the wrongfulness of his acts. Mental disease or defect does not otherwise constitute a defense.

Most state criminal laws followed this backlash by reducing the substantive scope of the insanity defence, shifting the burden of proof or abolishing it altogether (see below sub 2.2).

41 Durham v. United States, 214 F.2d p. 862, 874-5 (D.C.Cir. 1954).

42 See Model Penal Code, Comment 6 to $\$ 4.01$, vol. 3 pp. $180 \mathrm{ff}$.

43 United States v. Hinckley, 525 F. Supp. p. 1342 (D.D.C. 1981), aff'd, 672 F.2d p. 115 (D.C. Cir. 1982).

$44 \quad$ Pub. L. 98-473, title II, $\$ 402$ (a), Oct. 12, 1984, 98 Stat. 2057, $\$ 20$; renumbered $₫ 17$, Pub. L. 99 646, $\$ 34(a)$, Nov. 10, 1986, 100 Stat. 3599, codified in 18 U.S.C. $\$ 17$. 


\subsubsection{Burden of Proof, Role of Expert Testimony}

Legal orders of the civil law type, with an inquisitorial criminal procedure, examine the issue of imputabilitas ex officio. Usually, the burden of proof for all ingredients of the offence is placed on the state which has to prove that the defendant had the requisite state of imputabilitas, here soundness of mind, at the time of the alleged commission of the crime. This is often based on the presumption of innocence and in some countries has constitutional status.

English law ${ }^{45}$ and the vast majority of its descendants, ${ }^{46}$ however, proceed from a legal presumption of sanity which defendant has to rebut. More precisely, the defendant not only bears an evidential (evidentiary, provisional) burden to adduce some evidence of his insanity, but also bears the legal or persuasive (ultimate, probative) burden to establish his insanity on a balance of probabilities. An early American case ${ }^{47}$ and the Model Penal Code rejected this view and only placed the evidential burden on the accused who must introduce evidence supporting his claim of insanity, while the prosecutor must then disprove this affirmative defence and establish defendant's responsibility beyond a reasonable doubt. ${ }^{48}$ This view has not acquired constitutional status in the U.S., ${ }^{49}$ however, arguably because the traditional divide between elements of the offence on the one hand and defences on the other seems to have obscured the simple truth that all defences merely negate necessary conditions of responsibility so that soundness of mind is a 'fact constituting the offense'.

After the Hinckley verdict, the IDRA placed the legal burden on the defendant to prove by clear and convincing evidence that he was legally insane..$^{50}$ Also, a number of American States require proof of insanity by a preponderance of evidence, with the approval of the U.S. Supreme Court. ${ }^{51}$

Expert testimony is universally employed when mental disorders are at issue in court, but it seems that in most jurisdictions courts are not bound to follow the experts' opinion. It also seems to be a widespread if not universal experience that communication

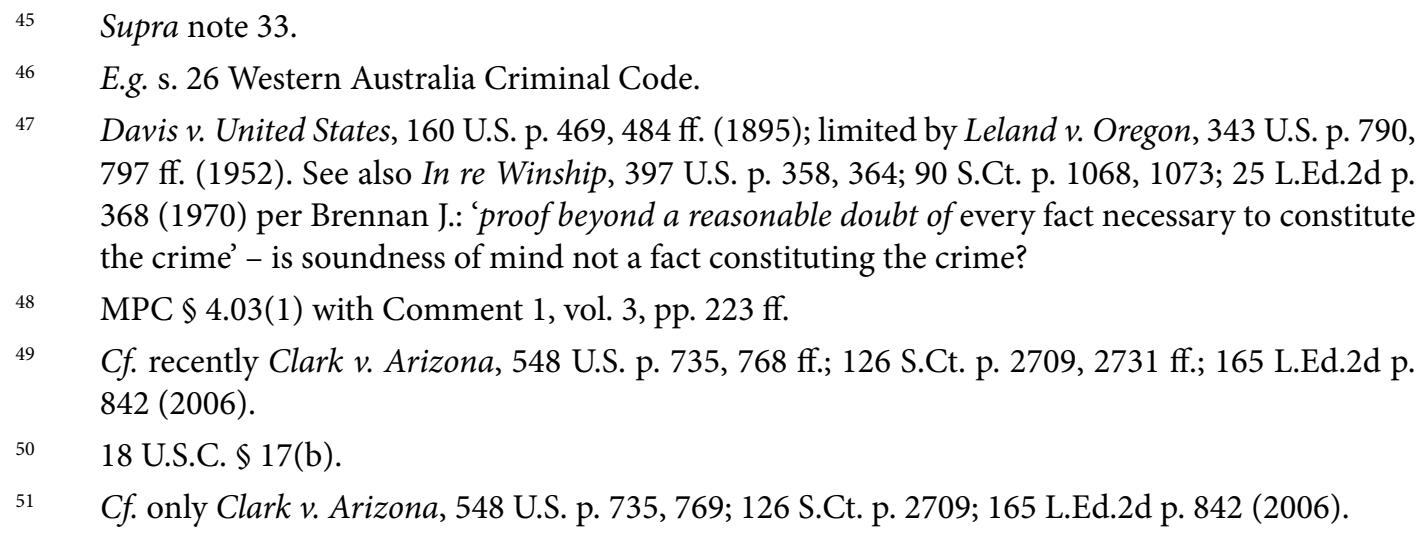


between medical experts and judges or juries is notoriously difficult and that the reliability of expert testimony is equally questionable as the courts' frequently uncritical reliance thereon..$^{22}$ These are inherent structural difficulties because the legal concepts of criminal responsibility and lack thereof, viz. insanity, can neither completely nor partially be reduced to or translated into medical categories and vice versa. ${ }^{53}$

\subsubsection{Legal Consequences (Verdict, Civil Commitment)}

In most European countries, a defendant found irresponsible will be acquitted. France replaced the acquittal in $2008^{54}$ by an arrêt portant déclaration d'irresponsabilité pénale pour cause de trouble mental ${ }^{55}$ which is said to better accommodate the victims' interests. ${ }^{56} \mathrm{In}$ the common law world, the traditional verdict 'not guilty by reason of insanity' has since the mid-1980s been replaced in some 20 American states by the oxymoronic formulas 'guilty but insane' or 'guilty but mentally ill. ${ }^{57}$

The legal consequence of an acquittal is that the accused goes unpunished. In most legal orders, an acquittal does not hinder protective measures (terminology varies: special sanctions, civil commitment etc.) like the commitment to a psychiatric institution if the accused is deemed dangerous. This is why, at least in Germany, defendants are said to be reluctant to raise the issue of insanity because most of them fear the stigma of insanity and the prospect of long-term confinement far more than ordinary prison. Commitment proceedings can be separate or integrated in the criminal trial. In England until 1991, the special verdict of insanity resulted in mandatory and indefinite commitment to a mental hospital; today, a hospital order, supervision or total discharge are in the court's discretion. In the second half of the 20th century, psychiatric treatment underwent substantial criticisms and reforms, and the liberty interests of institutionalised persons were strengthened. At least in the U.S., a large numbers of persons found 'not guilty by reason of insanity' are said to have been released after a rather short hospital time, a fact that has undermined public acceptance of the insanity defence. The novel 'guilty but mentally ill' verdict leads to punishment and in some, but not all states, also to psychiatric treatment of the convict. ${ }^{58}$

$52 \quad$ For a typical discussion see Gröning \& Rieber-Mohn 2015 pp. 115 f., 118-125.

53 Cf. only Clark v. Arizona, 548 U.S. p. 735, 775 ff.; 126 S.Ct. p. 2709; 165 L.Ed.2d p. 842 (2006).

54 Loi no 2008-174 du 25 février 2008 relative à la rétention de sûreté et à la déclaration d'irresponsabilité pénale pour cause de trouble mental, JO 26 février 2008.

55 Art. 706-130 French Code de procédure pénale.

56 Desportes et Le Gunehec, Droit pénal général, 16e éd. (Paris: Economica 2009), \$638-3 et s.

$57 \quad$ See Clark v. Arizona, 548 U.S. p. 735, 752 n. 19; 126 S.Ct. p. 2709; 165 L.Ed.2d p. 842 (2006) with further references.

$58 \quad$ E.g. Ariz. Rev. Stat. $\$ 13-3994(\mathrm{~A})$. 
Bergen Journal of Criminal Law and Criminal Justice • 1/2016

\subsection{Mental Disorder as Subcategory of Mistake/Involuntariness ('Mens Rea Model')}

In response to the Hinckley verdict, ${ }^{59}$ five American states - Idaho, Kansas, Montana, Nevada and Utah ${ }^{60}$ - have abolished the affirmative defence of insanity outright, e.g.

Idaho Code $\$ 18$-207:

(1) Mental condition shall not be a defense to any charge of criminal conduct. [...]

(3) Nothing herein is intended to prevent the admission of expert evidence on the issue of any state of mind which is an element of the offense...

Mental conditions are only relevant as causes for mistake, since prosecutors are 'still required to prove beyond a reasonable doubt that a defendant had the mental capacity to form the necessary intent. ${ }^{31}$ Insanity continues to be a relevant sentencing factor as well, since the courts have to assess ' $t$ ] he capacity of the defendant to appreciate the wrongfulness of his conduct ${ }^{\prime 62}$ and treatment is provided for mentally ill prisoners. This allows to convict e.g. schizophrenic persons who know what they are doing, but had no capacity to understand that it was wrong. ${ }^{63}$ Only the Nevada Supreme Court found the state statute in violation of the due process clause of the Nevada constitution. ${ }^{64}$ Other state courts upheld their legislation and the United States Supreme Court repeatedly declined to examine whether these statutes violated the federal constitution. ${ }^{65}$

\subsection{Mental Disorder Only Relevant for Choice of Sanction}

Neither infancy nor insanity constitute grounds for excluding criminal responsibility in Sweden - the situation in other Nordic countries is somewhat different and more similar

59 Legislative attempts to abolish the insanity defence are no novelty, but it seems that all of them failed in former times: In State v. Strasburg, 60 Wash. p. 106, 110 Pac. p. 1020 (Wash. 1910), the Washington Supreme Court declared unconstitutional a Washington statute that provided that insanity was not a defence; see also Sinclair v. State, 161 Miss. p. 142, 132 So. p. 581 (1931), where the Mississippi Supreme Court determined that the statute which stated that insanity was not a defence to the crime of murder was unconstitutional.

$60 \quad$ Idaho Code $\$ 18-207$; Kan. Stat. Ann. $\$ 22-3220$; Mont. Code Ann. $\$ \$ 46-14-102$, 46-14-311; NRS 193.220; Utah Code Ann. \$ 76-2-305.

$61 \quad 152$ Idaho p. 122, 125; 267 P.3d p. 709, 712 (2011).

$62 \quad$ Idaho Code $\$ 19-2523(1)(\mathrm{f})$.

63 Delling v. Idaho, 133 S.Ct. p. 504, 505 (2012), Breyer, J., dissenting; also State v. Bethel, 275 Kan. p. 456, 66 P.3d p. 840 (2003), cert. denied 124 S.Ct. p. 531, 157 L.Ed.2d p. 412 (2003).

64 Finger v. Nevada, 27 P.3d p. 66, 79 ff. (Nev. 2001).

$65 \quad$ Delling v. Idaho, 133 S.Ct. p. 504 (2012); see also Clark v. Arizona, 548 U.S. p. 735, 752 n. $20 ; 126$ S.Ct. p. 2709; 165 L.Ed.2d p. 842 (2006): leaving the question open. 
to Continental European countries ${ }^{66}$. In 1965, Sweden adopted legislation that followed the concept of individual or special prevention, focused on treatment and turned away from notions like guilt and punishment associated with moral blame. The more radical draft of 1956 even eliminated the term 'punishment' altogether. ${ }^{67}$ Hence, a mentally ill person can be prosecuted and convicted of a crime, provided he was able to form the necessary intent or to act negligently, but the mental disorder can mitigate the severity of the legal consequence and usually excludes prison sentences:

Chapter $29 \$ 3$ Brottsbalken:

In assessing penal value, the following mitigating circumstances shall be given special consideration in addition to what is prescribed elsewhere, if, in a particular case: ...

2. the accused, in consequence of a mental disturbance or emotional excitement, or for some other cause, had a markedly diminished capacity to control his actions,

3. the actions of the accused were connected with his manifestly deficient development, experience or capacity for judgement,

Chapter $30 \S 6$ :

Who has committed a criminal offense under the influence of a severe mental disorder, shall be sentenced to sanctions other than prison. The court may impose a prison sentence only for special reasons. In assessing whether special reasons are present, the court shall take into account:

1. if the crime has a high penal value

2. if the accused has no or only limited need of psychiatric care

3. if, in connection with the crime, the accused himself has induced his mental state by intoxication or otherwise

4. other factors.

(2) The court must not impose a prison sentence if, due to a severe mental disorder, the accused was incapable of appreciating the meaning of his conduct or adapt his behavior

66 For Denmark see Kramps, in: Placement and Treatment of Mentally Ill Offenders - Legislation and Practice in EU Member States, Final Report, eds. Salize and Dressing (Central Institute of Mental Health, Mannheim, Germany 2005) pp. 105-121. For Norway see supra notes $23 \mathrm{f}$.

67 Cornils, Schweden in: Nationales Strafrecht in rechtsvergleichender Darstellung, Allgemeiner Teil, vol. 5: Gründe für den Ausschluss der Strafbarkeit, eds. Sieber and Cornils (Duncker \& Humblot 2010) pp. 387-440, at $420 \mathrm{ff}$. 
in according with his appreciation. This does not apply if the accused caused his incapability as set out in para 1 no. 3.

(3) If the court finds pursuant to para. 1 or 2 that no sanction is necessary, then the accused will receive no penalty.

\subsection{Partial Excuse/'Diminished Responsibility'}

Many legal orders, mostly of the civil law type, recognise that imputabilitas, criminal responsibility, is a matter of degree so that punishment will be reduced in accordance with the degree of incapacity caused by the mental disorder. ${ }^{68}$ Common law countries traditionally only accepted a defence of diminished responsibility with regard to homicide, where it reduced a murder charge to manslaughter. Today's state of the law is very varied and often confused. ${ }^{69}$

\section{Final Remarks}

The interest of the public and of policy-makers in the excuse or defence of insanity, usually at its peak in the aftermath of acquittals in widely-publicised murder cases, by far exceeds its practical significance: While the defence of insanity is rarely raised and even less frequently successful in the common law world - there are said to be only around 15 successful insanity pleas in crown courts in England and Wales per year. ${ }^{70}$ Its use appears to be somewhat more frequent in civil law countries, notably the partial excuse of diminished responsibility due to intoxication - in 2013 in Germany, out of 935,788 accused, $749(0.08 \%)$ were found totally irresponsible and 17,968 (1.9\%) partially irresponsible. ${ }^{71}$

Also, it is an interesting as well as discomforting observation that modern times seem to be significantly less tolerant towards incompetent agents, like mentally ill offenders, than the previous two millennia. In contrast to all those beneficent achievements of scientific, notably medical progress, the understanding of what criminal law is all about apparently still leaves much to be desired when in some parts of the world many lawyers

68 E.g. Germany, Criminal Code, $\$ 21$; Spain, Código penal, art. 21 no.1; Italy, Codice penale, art. 89; France, Code pénal of 1995, art. 122-1\$2.

$69 \quad C f$. Ashworth \& Horder 2013 pp. 267 ff.; Loughnan 2012 pp. 226 ff.; Morse, 75 J. Crim. L. \& Criminology (1984) pp. 1-55; Sparr 2009 pp. 176 ff.; United States Sentencing Guidelines, $\$ 5 K 2.13$.

$70 \quad$ Ashworth \& Horder 2013 pp. $141 \mathrm{f}$.

71 Statistisches Bundesamt, Rechtspflege, Strafverfolgung, Fachserie 10 Reihe 3 (Statistisches Bundesamt 2013) p. 369. 
Carl-Friedrich Stuckenberg

obviously fail to grasp 'the implicit logic of every system of law: that the reach of law extends only to creatures able to comprehend its terms and abide by its prescriptions.72

$72 \quad$ Robinson 1996 p. 30. 